\title{
PENGARUH MEDIA PEMBELAJARAN TERHADAP HASIL BELAJAR PESERTA DIDIK KELAS VII MATA PELAJARAN IPS DI MTS NEGERI 1 SITUBONDO SEMESTER GENAP TAHUN PELAJARAN 2018/2019
}

\author{
Litianingsih $^{1}$, Dasucik ${ }^{2}$ \\ Pendidikan Ekonomi, STKIP PGRI Situbondo \\ Liptianingsih1997@gmail.com \\ Pendidikan Ekonomi, STKIP PGRI Situbondo
}

\begin{abstract}
Abstrak
Tujuan penelitian untuk mengetahui pengaruh media pembelajaran terhadap hasil belajar peserta didik kelas VII mata pelajaran ips di MTs Negeri 1 Situbondo tahun pelajaran 2018/2019.Teknik penentuan responden penelitian menggunakan populasi. Dari hasil penelitian yang diperoleh dengan menggunakan rumus analisis variansi garis regresi menghasilkan Ry $(1,2)$ empiric sebesar 0,537. Yang apabila dikonsultasikan dengan r-tabel dengan $\mathrm{N}$ sebanyak 100 responden dan taraf signifikansi 5\% diperoleh 0,197 perhitungan tersebut dimaksudkan untuk membuktikan hipotesa kerja mayor dengan menggukan uji signifikansi.Dari hasil perhitungan analisis variansi garis regresi diperoleh $F_{\text {reg }}$ sebesar 19,618. Dan apabila dikonsultasikan dengan $F$ table untuk $\mathrm{db}=2$ dan $\mathrm{db}=97$ dengan taraf signifikansi 5\% diperoleh 3,090. Dengan demikian dari hasil perhitungan tersebut menunjukkan Freg lebih besardari F-tabel. Berdasarkan analisa data dimuka, maka hipotesa kerja mayor yang berbunyi "Ada pengaruh media pembelajaran terhadap hasil belajar peserta didik kelas VII mata pelajaran IPS Di MTs Negeri 1 Situbondo semester genap tahun pelajaran 2018/2019"diterima. Efektifitas garis regresi dipreroleh sebesar $\mathbf{2 8 , 8 2 \%}$. Ini berarti sumbangan efektif dari keseluruhan predictor media visual dan media audio memberikan sumbangan sebesar $\mathbf{2 8 , 8 2 \%}$ dan variabel-variabel (faktor lain) yang tidak ikut di teliti sebesar $100 \%-28,82 \%=$ 71,18\%. Sumbangan efektif (SE) prediktor $\left(\mathrm{X}_{1}\right)$ media visual terhadap kriterium (Y) hasil belajar 10,65\%, sumbangan efektif (SE) prediktor $\left(\mathrm{X}_{2}\right)$ media audio terhadap hasil belajar (Y) 18,17\%, ini menunjukan bahwa media audio lebih berpengaruh terhadap hasil belajar disbanding media visual. Dengan melihat hasil data yang telah dipaparkan sebelumnya, maka dapat disimpulkan bahwa "Ada pengaruh media pembelajaran terhadap hasil belajar peserta didik kelas VII mata pelajaran IPS Di MTs Negeri 1
\end{abstract}

Situbondo semester genap tahun pelajaran 2018/2019”.

\section{Kata Kunci: Media Pembelajaran, Hasil Belajar Peserta Didik}

\begin{abstract}
The purpose of this study was to determine the effect of learning media on the learning outcomes of students in grade VII IPS subjects in MTs Negeri 1 Situbondo in the academic year 2018 / 2019. The technique for determining the research respondents used population. From the research results obtained using the regression line, variance analysis formula produces Ry (1.2) empiric of 0.537. Which when consulted with the $r-$ table with $\mathrm{N}$ as many as 100 respondents and a significance level of 5\% obtained 0.197 calculations are intended to prove the major working hypothesis by using a significance test. From the results of the calculation of the regression line variance analysis obtained Freg of 19,618. And when consulted with the F table for $\mathrm{db}=2$ and $\mathrm{db}=97$ with $\mathrm{a}$
\end{abstract}


significance level of 5\% obtained 3,090. Thus the results of these calculations show Freg is greater than the F-table. Based on data analysis upfront, the major work hypotheses that read "There is an influence of learning media on learning outcomes of VII grade students of Social Sciences in MTs Negeri 1 Situbondo" were accepted. The effectiveness of the regression line was obtained at $28.82 \%$. This means that the effective contribution of all visual and audio media predictors contributed $28.82 \%$ and variables (other factors) that were not examined were $100 \%-28.82 \%=71.18 \%$. Effective contribution (SE) predictor (X1) visual media to criterion (Y) learning outcomes $10.65 \%$, effective contribution (SE) predictor (X2) audio media to learning outcomes (Y) $18.17 \%$, this shows that audio media more influence on learning outcomes than visual media. By looking at the results of the data that have been presented previously, it can be concluded that "There is an influence of learning media on the learning outcomes of students of class VII social studies subjects at MTs Negeri 1 Situbondo.

\section{Keywords: Learning Media, Student Learning Outcomes}

\section{PENDAHULUAN}

Belajar adalah suatu proses perubahan dalam kepribadian manusia sebagai hasil dari pengalaman atau interaksi antara individu dan lingkungan.

Belajar-mengajar adalah suatu kegiatan yang bernilai edukatif. Nilai edukatif mewarnai interaksi yang terjadi antara guru dan peserta didik. Interaksi yang bernilai edukatif dikarenakan kegiatan belajar-mengajar yang di lakukan, diarahkan untuk mencapai tujuan tertentu yang telah diarahkan untuk mencapai tujuan tertentu yang telah di rumuskan sebelum pengajaran dilakukan.

Media pembelajaran merupakan alat bantu sekaligus partner bagi guru yang dapat mempercepat proses transfer materi pembelajaran. Media pembelajaran yang tepat dapat membantu guru yang mengalami kesulitan tertentu dalam menyampaikan materi pembelajaran, terutama jika materi pembelajaran tersebut menuntut peserta didik untuk terlibat secara langsung dalam materi pembelajaran yang disampaikan.

Oleh karena itu, menggunakan media dalam penyampaian materi ini mutlak diperlukan dan guru harus bisa memilih dan menggunakan media pembelajaran yang sesuai dengan tujuan yang ingin di capai agar peserta didik memperoleh hasil yang bagus. Dari uraian di atas penulis memandang pentingnya untuk mengadakan penelitian pengaruh media pembelajaran terhadap hasil belajar peserta didik pada mata pelajaran IPS di MTs Negeri 1 Situbondo.

Salah satu upaya untuk meningkatkan keaktifan siswa dalam proses pembelajaran adalah dengan menggunakan media dalam proses pembelajaran. Oleh karena itu, dalam rangka membantu guru dalam memecahkan masalah dalam pembelajaran, peneliti ingin menggunakan media pembelajaran visual dan audio pada mata pelajaran IPS. Hal ini ditujukan agar memudahkan peserta didik dalam memahami materi IPS sehingga dapat mempengaruhi hasil belajar siswa. 
Penelitian ini dilatarbelakangi oleh bagaimana cara menyajikan materi kepada peserta didik secara baik sehingga diperoleh hasil yang maksimal, kurangnya perhatian guru terhadap variasi penggunaan media pembelajaran dalam upaya peningkatan mutu pengajaran secara baik untuk mempermudah proses pembelajaran dengan menggunakan media pembelajaran.

Menyadari pentingnya media pembelajaran terhadap hasil belajar siswa maka penulis memilih judul "Pengaruh Media Pembelajaran Terhadap Hasil Belajar Peserta Didik Kelas VII Mata Pelajaran IPS Di MTs Negeri 1 Situbondo Semester Genap Tahun Pelajaran 2018/2019”.

Memahami pengertian peserta didik setidaknya bisa diselami dari tiga perspektif. Pertama, perspektif pedagogis, yang memandang peserta didik sebagai makhluk "homo educantum" atau disebut dengan makhluk yang membutuhkan pendidikan. Kedua, perspektif psikologis yang memandang peserta didik sebagai individu yang sedang dalam proses pertumbuhan dan perkembangan, bagi fisik dan psikis menurut fitrahnya masing-masing. Ketiga, perspektif Undang-Undang No. 20 tahun 2003 tentang sistem pendidikan nasional, dalam pasal 1 ayat 4, peserta didik adalah anggota masyarakat yang berusaha mengembangkan dirinya melalui proses pendidikan pada jalur jenjeng dan jenis pendidikan tertentu. (Priansa, 2017:22)

Kata media berasal dari bahasa Latin medius yang secara harfiah berarti tengah, perantara, atau pengantar. Dalam bahasa Arab media adalah perantara atau pengantar pesan dari pengirim kepada penerima pesan. Gerlach \& Ely (1971) mengatakan bahwa media apabila dipahami secara garis besar adalah manusia, materi atau kejadian yang membangun kondisi yang membuat siswa mampu memperoleh pengetahuan, keterampilan atau sikap. (Arsyad. azhar, 2013: 3)

Hintsman (Syah,2010:88) mengatakan "Learning is a change inorganism due to experince which can affect the organim's behavior" belajar adalah perubahan yang terjadi dalam diri organisasi (manusia atau hewan) disebabkan oleh perubahan pengalaman yang dapat memengaruhi tingkah laku organisme tersebut. (Priansa, 2017: 54)

Adapun media pembelajaran, sebagaimana Gagne (1970), adalah berbagai jenis komponen dalam lingkungan peserta didik yang dapat memotivasi pesrta didik untuk belajar.(Priansa, 2017: 130)

Media pembelajaran visual adalah media yang penyampaian pesannya terfokus melalui indra penglihatan. Jenis media visual merupakan salah satu media yang paling sering digunakan oleh guru dalam proses pembelajaran dikelas. Media visual terdiri atas media yang dapat di prokyeksikan (projected visual) dan media yang tidak dapat diprokyeksika (non-projected visual).(Priansa, 2017:141-142)

Media audio adalah media yang mengandung pesan dalam bentuk auditif (hanya dapat didengar) yang dapat di rangsang pikiran, perasaan, perhatian, dan kemauan peserta didik untuk mempelajari isi tema. Contoh media audio adalah program kaset suara dan program radio. (Priansa, 2017: 143) 
Menurut Sudjana (2004: 22) hasil belajar adalah kemampuan yang dimiliki siswa setelah ia menerima pengalaman pelajarannya. Sementara itu menurut Nasution (dalam Yohanes, 2013: 194) hasil belajar adalah hasil dari suatu interaksi tindak belajar dan mengajar dan biasnya ditujukan dengan nilai tes yang diberikan guru. Sedangkan hasil belajar menurut Burton (dalam Lufri, 2007:10) merupakan pola-pola perbuatan, nilainilai pengertian-pengertian, sikap, apresiasi dan keterampilan. (Yulia, n.d.)

\section{METODE PENELITIAN}

Jenis penelitian yang digunakan dalam penelitian ini adalah non-eksperimental dengan menggunakan expost facto, karena penulis ingin mengetahui mengenai pengaruh media pembelajaran terhadap hasil belajar peserta didik. Rancangan penelitian ini adalah penelitian dua arah yang tujuannya ingin mengetahui apakah ada pengaruh variabel bebas terhadap variabel terikat.

Teknik penentuan lokasi yang digunakan adalah Purposive Sampling Area karena tempat penelitiannya hanya ada satu tanpa ada pihak lain. Penelitian ini akan dilaksanakan di MTs Negeri 1 Situbondo.Penentuan daerah tersebut memenuhi syarat untuk dijadikan obyek penelitian.

Penentuan responden penelitian dapat dilakukan dengan dua cara yaitu dengan populasi atau sampel secara maksudnya individu, keadaan, serta benda dijadikan sumber data dimana data dianalisis untuk membuktikan hipotesis. Penelitian sampel adalah sebagian atau bagian dari populasi yang diharapkan dapat mewakili populasi serta mencerminkan keadaan populasinya. Dalam penelitian ini menggunakan populasi dengan sampel kelas VII di MTs Negeri 1 Situbondo.

Pengumpulan data dalam penelitian dilakukan menggunakan beberapa macam tekhnik, yaitu : observasi, dokumentasi, angkaet dan wawancara. Setelah data terkumpul melalui berbagai metode pengumpulan data diatas maka selanjutnya dilakukan pengolahan data menjadi data yang siap dianalisis. Tehnik pengolahan data analisa data yang peneliti lakukan melalui tahap-tahap sebagai berikut : editing, koding, tabulasi

Didalam penelitian ini digunakan analisa dua prediktor karena variabel bebas terdiri dari media pembelajaran visual (X1), dan media pembelajaran audio (X2) merupakan variabel bebas, sedangkan yang digunakan untuk meramalkan hasil belajar peserta didik (Y) merupakan variabel terikat. Dan digunakan rumus regresi linear dengan dua prediktor yaitu untuk mengetahui berapa besar pengaruh variabel bebas terhadap variabel terikat.

Dalam hal ini peneliti ingin mencari seberapa besar pengaruhnya untuk itu, analisa yang digunakan sebagai berikut:

\section{Uji Validitas}

Secara statistik angka korelasi harus di bandingkan denganangka kritik tabel korelasi nilai - $\mathrm{r}$ apabila nilai $\mathrm{r}$ - krikti. 


$$
\mathrm{r}_{\mathrm{xy}}=\frac{N \sum X Y-\left(\sum X\right)\left(\sum Y\right)}{\sqrt{\left\{\left(N \sum X^{2}-\left(\sum X\right)^{2}\right)\left(N \sum Y^{2}-\left(\sum Y\right)^{2}\right)\right\}}}
$$

Keterangan:

$$
\begin{aligned}
& r_{X Y} \quad=\text { Korelasi product moment } \\
& X=\text { Skor total dari setiap item } \\
& Y=\text { Skor/nilai dari setiap item } \\
& N=\text { Jumlah sampel }
\end{aligned}
$$

\section{Uji Reliabilitas}

Dalam pengujian reliabilitas dilakukan dengan menggunakan teknik Alpha Cronbach, yang rumusnya sebagai berikut:

$$
r_{11}=\left[\frac{k}{(k-1)}\right]\left[1-\frac{\sum \sigma b^{2}}{\sigma t^{2}}\right]
$$

$$
\begin{array}{ll}
r_{11} & =\text { reliabilitas instrumen } \\
k & =\text { banyaknya butir pertanyaan atau banyaknya soal } \\
\Sigma \sigma b^{2} & =\text { jumlah varians butir } \\
\sigma t^{2} & =\text { varians total }
\end{array}
$$

\section{Persamaan Garis Regresi}

Untuk menemukan persamaan garis regresi, harga-harga koefisien prediktor dan bilangan konstantanya dapat dicari dari data yang diselidiki. Adapun rumus yang digunakan dalam mencari persamaan garis regresi adalah sebagai berikut:

$$
Y=a_{1} X_{1}+a_{2} X_{2}+K
$$

\section{Mencari Koefisien Korelasi Berganda}

$$
\mathrm{Ry}_{(1,2,)}=\sqrt{\frac{a_{1} \sum x_{1} y+a^{2} \sum x_{2} y}{\sum y^{2}}}
$$

Keterangan :

$\mathrm{Ry}_{(1,2)}=$ Koefisienkorelasi antara $\mathrm{Y}$ dengan $\mathrm{X}_{1}$ dan $\mathrm{X}_{2}$

$\mathrm{a}_{1} \quad=$ Koefisienprediktor $\mathrm{X}_{1}$ 
$\mathrm{a}_{2} \quad=$ Koefisienprediktor $\mathrm{X}_{2}$

$\mathrm{X}_{1} \mathrm{Y}=$ JumlahProduk antara $\mathrm{X}_{1}$ dengan $\mathrm{Y}$

$\mathrm{X}_{2} \mathrm{Y}=$ JumlahProduk antara $\mathrm{X}_{2}$ dengan $\mathrm{Y}$

$y^{2} \quad=$ Jumlah kuadrat Kreterium

\section{Mencari Koefisien Korelasi Partial}

Setelah itu dilakukan perhitungan koefisien korelasi variabel terikat (Y) dengan dua variabel bebas $\mathrm{X}_{1}, \mathrm{X}_{1}$ yakni dengan rumus $\mathrm{Ry}_{(1,2)}$. Kemudian dilanjutkan dengan menghitung koefisien korelasi partialnya dengan menggunakan formulasi :

$$
R y_{1(2)}=\frac{R y_{1}-R y_{2} R y_{12}}{\sqrt{\left(1-R^{2} Y\right)\left(1-R^{2}{ }_{1,2}\right)}}
$$

\section{Analisis Variansi Garis Regresi}

$$
\mathrm{F}_{\text {reg }}=\frac{R^{2}(N-m-1)}{m\left(1-R_{2}\right)}
$$

Dimana :

$$
\begin{aligned}
& \mathrm{R}^{2}=\mathrm{Ry}_{(1,2)} \text { dikuadratkan } \\
& \mathrm{N}=\text { Banyaknya data } \\
& \mathrm{m}=\text { Banyaknya variabel bebas }
\end{aligned}
$$

\section{Uji t}

Uji $t$ pada dasarnya menunjukkan seberapa jauh pengaruh satu variabel independen secara individual dalam menerangkan variasi variabel independen (Imam Ghozali, 2010).

$$
\mathrm{t}=\frac{R \sqrt{n-2}}{\sqrt{1-R^{2}}}
$$

Keterangan :

$$
\begin{array}{ll}
\mathrm{R} & : \text { Koefisien Korelasi } \\
\mathrm{R}^{2} & \text { : Koefisien Determinasi } \\
\mathrm{n} & : \text { Banyaknya sampel }
\end{array}
$$

\section{Efektifitas Garis Regresi (EGR)}

$$
\begin{array}{r}
\mathrm{JK}_{\text {reg }}=\mathrm{a}_{1} \Sigma \mathrm{x}_{1} \mathrm{y}+\mathrm{a}_{2} \Sigma \mathrm{x}_{2} \mathrm{y} ; \mathrm{Jk}_{\mathrm{tot}}=\Sigma \mathrm{y}^{2} \\
\mathrm{EGR}=\frac{J K_{\text {reg }}}{J K_{\text {tol }}} x 100 \%
\end{array}
$$




\section{Sumbangan Efektif (SE)}

Sedangkan untuk menghitung sumbangan efektif (SE) atau besar pengaruh masing-masing (variabel bebas) terhadap (variabel terikat) adalah sebagai berikut:

$$
\begin{aligned}
& \mathrm{SE} \% \mathrm{X}_{1}=\frac{a_{1} \sum x_{1} y}{J K_{r e g}} \times 100 \% \\
& \mathrm{SE} \% \mathrm{X}_{2}=\frac{a_{2} \sum x_{2} y}{J K_{r e g}} \times 100 \%
\end{aligned}
$$

\section{HASIL PENELITIAN}

Penentuan responden penelitian ini menggunakan metode proporsional random sampling. Dari jumlah 171 peserta didik kelas VII kami ambil 100 peserta didik: Adapun rincian jumlah responden perkelas dalam penelitian ini adalah sebagai berikut:

1. Kelas VII $A=\frac{26}{171} \times 100=15$ peserta didik

2. Kelas VII B $=\frac{27}{171} \times 100=16$ peserta didik

3. Kelas VII C $=\frac{25}{171} \times 100=15$ peserta didik

4. Kelas VII D $=\frac{33}{171} \times 100=19$ peserta didik

5. Kelas VII E $=\frac{31}{171} \times 100=18$ Peserta didik

6. Kelas VII F $=\frac{29}{171} \times 100=17$ Peserta didik

Data tentang media pembelajaran didapatkan melalui angket disebarkan kepada responden. Setiap nomor pada angket mempunyai 3 alternatif jawaban dan penilaian terhadap hasil angket untuk masing-masing nomor dengan ketentuan-ketentuan sebagai berikut:

1. Jawaban A diberi nilai 3

2. Jawaban B diberi nilai 2

3. Jawaban $\mathrm{C}$ diberi nilai 1

Untuk mengetahui ada tidaknya pengaruh media pembelajaran terhadap hasil belajar, maka menggunakan rumus analisis regresi 2 prediktor langkah-langkah yang dilakukan dalam menganalisa data dengan menggunakan analisis linear 2 prediktor.

Uji validitas dilakukan pada seluruh pernyataan dalam instrumen dengan cara mengkorelasikan skor tiap pertanyaan dengan skor totalnya. Teknik korelasi yang digunakan adalah korelasi Product Moment. Data diolah dengan bantuan Microsoft Excel dan program SPSS for Windows release 20.0. Hasil uji validitas terhadap skorskor variabel adalah sebagai berikut: 


\begin{tabular}{|c|c|c|c|c|c|c|}
\hline Variabel & $\mathrm{r}_{\text {hitung }}$ & $\begin{array}{l}r_{\text {tabel }} 5 \% \\
(\mathrm{db}=100)\end{array}$ & Interpretasi & $r_{\text {hitung }}$ & $\begin{array}{l}r_{\text {tabel }} 5 \% \\
(\mathrm{db}=100)\end{array}$ & Interpretasi \\
\hline \multicolumn{4}{|c|}{ Media Pembelajaran Visual } & \multicolumn{3}{|c|}{ Media Pembelajaran audio } \\
\hline 1 & 0,341 & 0,197 & Valid & 0,725 & 0,197 & Valid \\
\hline 2 & 0,578 & 0,197 & Valid & 0,774 & 0,197 & Valid \\
\hline 3 & 0,292 & 0,197 & Valid & 0,734 & 0,197 & Valid \\
\hline 4 & 0,517 & 0,197 & Valid & 0,721 & 0,197 & Valid \\
\hline 5 & 0,326 & 0,197 & Valid & 0,495 & 0,197 & Valid \\
\hline 6 & 0,600 & 0,197 & Valid & 0,374 & 0,197 & Valid \\
\hline 7 & 0,458 & 0,197 & Valid & 0,501 & 0,197 & Valid \\
\hline 8 & 0,280 & 0,197 & Valid & 0,317 & 0,197 & Valid \\
\hline 9 & 0,260 & 0,197 & Valid & 0,504 & 0,197 & Valid \\
\hline 10 & 0,694 & 0,197 & Valid & 0,670 & 0,197 & Valid \\
\hline
\end{tabular}

Dari masing-masing hasil nilai korelasi tersebut, kemudian dikonsultasikan dengan nilai $\mathrm{r}$ tabel pada taraf signifikansi $5 \%$ dan pada $\mathrm{db}=\mathrm{N}-1=100-1=99$, dimana $r$ tabelnya $\left(r_{t a b}\right)$ sebesar 0,197 , sehingga dapat dilihat. Jika besar $r$ hitung $\left(r_{\text {hit }}\right)$ lebih kecil dari pada $r$ tabel $\left(r_{\text {tab }}\right)$, maka soal tersebut tidak valid dan perlu di revisi, tetapi apabila $r$ hitung $\left(r_{\text {hit }}\right)$ lebih besar daripada $r$ tabel $\left(r_{\text {tab }}\right)$ maka soal tersebut dapat dikatakan valid.

Uji reliabilitas bertujuan untuk mengetahui keandalan kuesioner yaitu sejauh mana suatu alat pengukur dapat dipercaya atau diandalkan dan tetap konsisten jika dilakukan dua kali atau lebih pada kelompok yang sama dengan alat ukur yang sama. Pengujian Cronbach Alpha digunakan untuk menguji tingkat keandalan (reliability) dari masing-masing angket variabel. Data diolah dengan bantuan Microsoft Excel dan program SPSS for Windows release 20.0. Hasil uji validitas terhadap skor-skor variabel adalah sebagai berikut.

\begin{tabular}{|l|c|c|c|}
\hline \multicolumn{1}{|c|}{ Variabel } & Koefisien Alpha & $\mathrm{r}_{\text {tabel }} 5 \%$ & Interpretasi \\
\hline Media Pembelajaran Visual & 0,563 & 0,197 & Reliabel \\
\hline Media Pembelajaran audio & 0,788 & 0,197 & Reliabel \\
\hline
\end{tabular}

Dari hasil perhitungan analisis variansi garis regresi diperoleh $F_{\text {reg }}$ sebesar 19,618. Dan apabila dikonsultasikan dengan $\mathrm{F}$ tabel untuk $\mathrm{db}=2$ dan $\mathrm{db}=97$ dengan taraf signifikansi 5\% diperoleh 3,090. Dengan demikian dari hasil perhitungan tersebut menunjukkan Freg lebih besar dari F-tabel yang berarti signifikansi secara media pembelajaran terhadap hasil belajar.

1. Sumbangan variabel bebas $(\mathrm{X})$ terhadap variabel terikat (Y) dari keseluruhan variabel yang ada (tanpa adanya faktor lain) maka besar 
sumbangannya adalah untuk $\mathrm{X}_{1}$ sebesar $10,65 \%$ sedang untuk faktor $\mathrm{X}_{2}$ sebesar $18,17 \%$

2. Sumbangan variabel bebas $(\mathrm{X})$ terhadap variabel terikat $(\mathrm{Y})$ apabila terdapat variabel lain selain variabel bebas $(\mathrm{X})$ maka besar sumbangannya $71,18 \%$

3. Jika sumbangan variabel bebas keseluruhan sebesar $28,82 \%$ maka besar sumbangan variabel bebas $\mathrm{X}_{1}$ sebesar $10,65 \%$ dan besar sumbangan variabel bebas $\mathrm{X}_{2}$ sebesar $18,17 \%$.

4. Pengaruh keseluruhan variabel media pembelajaran yang diteliti terhadap hasil belajar adalah sebesar 28,82\%

Pada pengujian hipotesis minor 1 adalah ada pengaruh rendah yaitu antara media pembalajaran visual terhadap hasil belajar peserta didik. Sedangkan pada minor 2 ada pengaruh sedang antara media pembelajaran audio terhadap hasil belajar peserta didik.

Media audio adalah media yang mengandung pesan dalam bentuk auditif (hanya dapat didengar) yang dapat di rangsang pikiran, perasaan, perhatian, dan kemauan peserta didik untuk mempelajari isi tema. Contoh media audio adalah program kaset suara dan program radio. Penggunaan media audio dalam kegiatan pembelajaran bertujuan melatih keterampilan yang berhubungan bertujuan melatih keterampilan yang berhubungan dengan aspek keterampilan mendengarkan. Media ini mengandung kelemahan sehingga harus diatasi dengan cara memanfaatkan media lainnya. (Priansa, 2017: 143)

\section{KESIMPULAN DAN SARAN}

Setelah penulis menganalisis semua data yang diperoleh dari hasil penelitian tentang pengaruh media pembelajaran terhadap hasil belajar peserta didik kelas VII mata pelajaran IPS Di MTs Negeri 1 Situbondo semester genap tahun pelajaran 2018/2019, maka penulis dapat mengambil kesimpulan sebagai berikut:

\section{Simpulan Umum}

Ada pengaruh media pembelajaran sebesar 0,537 terhadap hasil belajar peserta didik kelas VII mata pelajaran IPS Di MTs Negeri 1 Situbondo semester genap tahun pelajaran 2018/2019.

\section{Simpulan Khusus}

1. Ada pengaruh media pembelajaran visual sebesar 0,260 terhadap hasil belajar peserta didik kelas VII mata pelajaran IPS Di MTs Negeri 1 Situbondo semester genap tahun pelajaran 2018/2019.

2. Ada pengaruh media pembelajaran audio sebesar 0,462 terhadap hasil belajar peserta didik kelas VII mata pelajaran IPS Di MTs Negeri 1 Situbondo semester genap tahun pelajaran 2018/2019. 


\section{REFERENSI}

Algifari . 2000. Analisis Regresi edisi 2. Yogyakarta : Bpfe-Yogyakarta

Arsyad, Azhar. 2013. Media Pembelajaran. Jakarta: PT Raja GrafindoPersada.

Asnawir dan Basyiruddin. 2012. Strategi Belajar Mengajar. Bandung: Pustaka Setia

Aqil, Zainal. 2013. Model-model dan Strategi Pembelajaran Kontekstual (Inovatif).

Bandung: CV Yrama Widya

Aunurrahman. 2014. Belajar dan Pembelajaran. Bandung: Alfabeta.

Daryanto. 2011. Belajar \& Pembelajaran. Yogyakarta: Teras

Dr.Riduwan, M. B.2012. Belajar Mudah Penelitian Untuk Guru, Karyawan dan

Peneliti Pemula. Bandung: Alfabeta.

Hadimiarso. 2014. Berbagai Pendekatan dalam Proses Belajar Mengajar . Jakarta: PT Bina Aksara

Hamalik. 2013. Media Pembelajaran. Jakarta: Raja Grafindo Persada

Hamzah. 2011. Teknologi Komunikasi \& Informasi Pembelajaran. jakarta: PT Bumi Aksara.

Priansa, J. D. 2017. Pengembangan Strategi \& Model Pembelajaran. Bandung: CV Pustaka Setia.

Sudjana, Nana. 2011. Penilaian Hasil Proses Belajar Mengajar. Bandung : PT. Remaja Rosdakarya.

Sudjana, Nana and Rivai, Ahmad. 2015. Media Pengajaran. Bandung: Sinar Baru Algensido

Sunyoto, Danang. 2011. Metodelogi Penelitian Ekonomi. Yogyakarta : Caps.

Sunyoto, Danang . 2011. Statistik Deskriptif untuk Ekonomi. Bandung : CV Yrama Widya.

Yulia, D. (n.d.). Pengaruh Penggunaan Media Film Animasi dalam Pembelajaran IPS Terpadu Terhadap Hasil Belajar Siswa. 